\title{
The Apparatus of Ideology: A post-Colonial Reading of English Literature; Considerations from 'Institutional Literatures'
}

\author{
Ayman, M. Abu-Shomar \\ King Saud University, Riyadh, KSA
}

Received: 11-06- 2013

Accepted: 3-07- 2013

Published: 31-07- 2013

doi:10.7575/aiac.ijclts.v.1n.2p.17

URL: http://dx.doi.org/10.7575/aiac.ijclts.v.1n.2p.17

\begin{abstract}
This paper reviews the concept and the corpus of English literature and its development in the context of culture and the academy from the $18^{\text {th }}$ Century onwards. I argue that the category of literature is a 'liquid' notion best understood as a form of 'social action' (after Eagleton) relevant to wider social, cultural, and political contexts that produce and 'consume' it. In the academy, through extending the notion of the institution to a wider social and political context, literature could be best understood as an 'institutional reality' reflecting perceived relations of power. Deeming literature as an ideological tribute is crucially important to arguing against the monolithic and essentialist (AngloAmerican literary tradition) as embodying a universal value that still prevail in post-colonial institutions. This argument helps conceptualise and interrogate the cultural constructs embodied in English literature, in general, and the English canonical texts, in particular; it also makes it possible to refute the claim that literature transcends its local boundaries and nationalist sentiments to articulate the universal concerns and values of all people. In my approach to these claims and assumptions, I resort to a critical narrative review to the 'story' of the English literature in cultural, political, social, geographical and institutional contexts.. In academy, particularly in post-colonial settings, I conclude that the adopted literary tradition reflects a matrix of relations of power and institutional affiliations. Such conceptualisation of literature helps to challenge the claim that English literature largely embodies a humanistic enterprise of universal values and uniform human experience.
\end{abstract}

Keywords: English Literature, Cultural studies, Critical Theory, Post-colonialism

\section{Introduction}

Prior to developing an understanding of the category of literature, it might be helpful to tackle the concepts of 'institution' and 'society' and their relation to literature. While society is taken to be the wider arena that shelters the institution and determines its existence, institutions, are the active agents that own the volition of what the society should or should not include (Fowler, 1999). The institutionalisation of literary studies plays a crucial role in defining the category of literature and deciding which writers and texts deserve inclusion in the canon. In this respect, I expand the concept of the institution to include any agents involved in the 'profession' (Graft, 1987) of the literary tradition. Literary institutions are large social networks whose members, literary or non-literary workers, regulate the complex process of classifying, valuing, and disseminating the works of literature. Therefore, institutionalising literature involves a collective body of institutions that constitute the literary system in which each institution influences the way literature is viewed, and therefore performs a social function as gatekeeper between the literary work and its audience (Westhuizen, 2004). This network includes literary critics, reviewers, publishers, literary prize committees, and other agents within the educational, economic, and artistic subsystems of society.

The idea of literature as a form of 'social action' (Eagleton, 1996) might be understood as an antithesis to the modernist view of 'art-for-art's sake' that takes literature to transcend its local boundaries and nationalist sentiments to articulate the universal concerns and values of all people. Although this idea began in the era of progressive modernism, it is originated with a call to free artists whose aesthetic visions should neither comply with the formal rules of academic art, nor seek social approval (Chin, 2006). Nonetheless, this ideal call for aesthetic freedom was easier proclaimed than achieved and was manipulated in a way to propagate the claim of the universality of English literature. In reality, English literature, to a large extent, is fraught with social and political implications. It also resonates with the historical experience of societies and individuals that constitute another reality of literature, not only for those in favour of the classics, but also for those who embrace counter positions, such as post-colonial literatures. The idea of social action refers to a certain group's ideology that shapes all cultural productions of that group, and/or an individual's ideology that is shaped by the prescribed boundaries of the dominant discourse of the society (Bourdieu, 1984). Yet, it is important to notice that any form social action exercises its power in unstable sites of ideological contestations, and in discursive ways that are shaped by different socio-political and cultural contexts. Institutions are a specific category within a society that bears responsibility for the cultural products of its society and those of other societies (Bourdieu, 1983). As I shall argue below, the idea of institution is connected to academic literary study, or what Graft (1987) calls the 'professionalization' and 'academicisation' of literature. 
Literature has been subordinate to the fluidity of cultural tenets, which in themselves have undergone several historic, paradigmatic, and institutional transfigurations and perversions. Both the notions of culture and literature are subject to similar social and historical trajectories. 'Institutionalising' literature has epitomised the concept and determined its value, and how it mirrors wider cultural relations of power. Drawing on these observations, I argue that there always exists interplay between the text and the wider context responsible for producing and disseminating literature, which intersects with institutionally established ideologies and practices. I understand the notion of context to refer to the 'system' or the 'institutional cultural capital' (Bourdieu, 1998) that is responsible for normalising and regulating textual knowledges, and which projects literature as an 'institutional reality'. As Popatia (1998) argues, the interaction between text and context is often governed by an ideological and hegemonic discourse that seeks to prove itself as the most legitimate.

Specifically, while the English literary tradition, canonised texts, in particular, is claimed to epitomise a humanistic enterprise that claims for universality of values and uniformity of human experience, this hegemonic enterprise takes the 'other' as essentially identical to the 'self' (Ashcroft, et al., 1989). I argue that this tradition creates an enduring relationship between particular ideologies and the general social taste, where the 'institution' deems itself as having absolute authority over what is valuable or not. As Foucault (1970) reminds us, people are inculcated into hegemonic systems of reasoning and the 'school' becomes a site where it is possible to resist dominant discursive practices. After Bourdieu (1998), I understand the notion of 'institutional protocols' that underpins access to the means of literary production and consumption a praxis that aims to preserve, reproduce, and disseminate particular literatures or a 'tradition' over successive generations. Thus, Bauman's (2000, 2001) 'liquid' or 'liquidity' provides an outstanding metaphor for understanding the volatility of the concept of literature, and how it is shaped by the social and historic vessels that nurture it, particularly in academic settings.

\section{The notion of 'English' literature}

The concept of literature though seemingly simple, is a rather difficult one to grasp. This, in part, stems from its conventional contemporary meaning that appears prima facie simple. The difficulty appears when we ask whether all books and writings are literature, and if not, which kinds are to be excluded and by what criteria (Williams, 1983). Tracing the historical development and the ways the term has been used in the English context by various intellectuals at various times, Williams concludes that what has been often referred to by the concept literature is not a static and well-defined object, but a fluid entity shaped by various intellectual conventions.

The general sense of the term was associated with the idea of 'polite reading' and was firmly attached to printed books, which was the underlying basis of the later specialisation. The first signs in the change of meaning, however, appeared in the eighteenth century, when the term literacy was extended beyond its equivalence to literate where the idea of polite learning had been the criteria to describe both the way of reading and writing works. The philosophical works of Hume, for example, were considered to be literature because they contribute to polite learning. In the eighteenthcentury, "all works within the orbit of polite learning came to be described as literature and all such interests and practices as literary" (Williams, 1983, p. 185).

It is difficult to identify any clear features of literary texts or to identify any clear boundaries between literary or nonliterary language. In his argument that literature does not exist in independent of identifiable linguistic phenomena or of readers and contexts of reading, Hall (2005) concludes that the category of "literature is made of, from and with ordinary language, which is itself already surprisingly literary" (p. 10). Although working from a different perspective, deconstructing the boundaries between literary and ordinary language, Hall concludes that the literary/non-literary divide according to strictly linguistic principles does not exist. He claims that identifying literature as old-fashioned, obscure, pretentious or 'the best that is known and thought in the world' is not a matter of intrinsic and inherent linguistic features of literary work, but rather a rationale which lies behind institutional practice particularly, "the traditional modern foreign language curriculum which culminates in the study of literature, with the implication that the literary classics represent in some sense 'the best' uses of the language to date... and therefore an appropriate model for students to revere, if not aspire to" (p. 11).

For a text to be taken as literature and hence to be included in a curriculum requires much more than its essential linguistic features; it needs a form of institutional 'linguistic capital', or to be "the means by which one attains to a socially credentialed and therefore valued speech, otherwise known as 'standard English"' (Guillory, 1993, p. ix). This conscious or more often unconscious tradition maintains the status quo of an unjustified rationale about the notion of 'standards' that has emerged from historical consideration of the styles of literature in the modern ages. Works studied today as literature in English classes in many universities were once treated, not as a special kind of writing, but as fine examples of the language best use and rhetoric (Culler, 1997, p. 21).

Furthermore, the notion of modern 'literary theory' which has been set out to approach literature and to draw boundaries of literary works consolidates the idea of the fluidity of the notion of literature. It also proves that the category of literature is consistently configured according to the social and institutional demands. Modern literary theory might be dated back to 1917, when the Russian Formalists defined literature as a peculiar kind of language use. They saw literature as an intensification of ordinary language that systematically deviated from everyday speech. Their baseline argument is that 'estranging' or 'defamiliarising' everyday language in literary works forces a dramatic awareness and refreshes the habitual discourses that often become stale, blunted or automatized (Hall, 2005). They believed that "literary discourse estranges or alienates ordinary speech, but in doing so, paradoxically, brings us into a fuller, more intimate possession of experience" (Eagleton, 2008, p. 4). 
The counter argument of such an assumption underlies the fact that there is no single 'normal' language equally shared by all members of society, since one's norms may be another's violation. Furthermore, ordinary or actual language consists of a wide range of discourses differentiated according to class, region, gender, and status, which cannot be unified by a single homogeneous linguistic unity (Hall, 2005). More importantly, both the norms and deviations shift around from one social or historical context to another. For a piece of language to be made 'strange' does not guarantee that it is so always and everywhere. The only way to decide what is literary is when it announces itself as such, or when it is put on a university literature syllabus (Eagleton, 2008). Literary theories particularly, those that emerged towards the second half of the twentieth century, intermingles ideas from linguistics, history, political theory, and psychoanalysis theorists. The traditional binary distinction of literary/non-literary is no longer methodologically crucial; the project of literary theory can be approached through both literary and non-literary works; Virginia Woolf's novels or Freud's case histories, for example, might be analysed in a similar way for the same purpose (Culler, 1997).

Other theoretical positions, such as the stand that takes literature to be 'non-practical' or 'non-pragmatic' discourse seem to fail to define the category of literature. To define literature as 'non-pragmatic' discourse, i.e. as not intended to serve an immediate practical purpose, is again not free from problems. In fact such a claim is self-defeating since "if treating discourse 'non-pragmatically' is a part of what is meant by 'literature', then it follows from this 'definition' that literature cannot be read as 'objectively' defined, for as Eagleton confirms, "It leaves the definition of literature up to how somebody to decides to read, not to the nature of what is written" (Eagleton, 2008, p. 7). Although many poems, plays, or novels are not meant to be read pragmatically, there is no guarantee that they are not read as such. In many contexts literature has served highly practical functions, religious or political, which blurs the distinction between practical and non-practical work (ibid).

Reader response theory anchors this argument, since relying on the reader as an active agent to decide not only about the text, but also to pass value-judgements on it. Hall (2005) discusses practitioners and researchers who argue literature is best understood as a kind of reading; concluding that it is "difficult to think of literature without considering reading" (p. 83). Nonetheless, critical reader response theory, that is the tradition of various critical stances, such as those of feminism and post-colonialism, have questioned the identity of the reader since different readers or the same readers on different occasions may respond differently to the same text. 'Interpretive communities' or what Holliday (1999) calls 'small cultures' determine whether a work is literary or not. Hall (2005) defines these cultures or communities as "the institution(s) of literature, principally educational sites and systems" (p. 94). He contends that literature is

seen as a social practice: exam boards set texts to read, teachers are trained in approved methods, literature is an institutional practice. Approval and sanction will not be given to unorthodox ideas that do not meet with the consensus of professional peers and superiors, and so will not be disseminated and taken up more widely (p. 94).

As stated by Ellis, literature is like a 'weed', since weeds are not a particular kind of plants, but rather any plant that a 'gardener', for whatever reason, does not want around (quoted in Eagleton, 2008, p. 8). Thus both 'weeds' and 'literature' are functional, rather than ontological entities: "They tell us about the role of a text or a thistle in a social context, its relation with and differences from its surroundings, the ways it behaves, the purposes it may be put to and the human practices clustered around it. Literature in this sense, is a purely formal, empty sort of definition" (Eagleton, p. 8) [emphasis added]. In his attempt to define literature, Culler (1997) reaches a similar conclusion: "it is tempting to give up and conclude that literature is whatever a given society treats as literature- a set of texts that cultural arbiters recognise as belonging to literature" (p. 22).

\section{The fall of the paradigm}

The scientific community works within a paradigm, a consensus of methods and ends. As time passes, however, new evidence or contradictions within the paradigm accumulate and it falls into doubt. Then, a crisis arises, a new paradigm emerges, and old theoretical questions are deserted. Paradigms govern both theory and practice; they are both an entire constellation of beliefs, and the concrete puzzle-solutions that took place with them (Kuhn, quoted in Easthope, 1991, p. 3). Easthope (1991) contends that literature has a similar status. Although the status of literature once rested on a seemingly unchallenged foundation, the last decades of the twentieth century has disturbed these foundations.

Reviewing the development of literary studies, Easthope contends that the old paradigm of English literary studies has collapsed. Within a period of two generations, "modern literary study was invented, institutionalised in the academy, fell into crisis, and is now being transformed into something else; cultural studies ... the moment of crisis symptomatically registered in concern with theory is now passing, and that a fresh paradigm has emerged, its status as such proven because we can more or less agree on its terms and use them" (p. 5) [emphasis added].

In his argument against a unified paradigm of literary study, Easthope asserts that a universal definition of paradigm is neither possible nor desirable, since "to some extent theory and to a much larger extent ways of demonstrating facts will be appropriate and specific to a particular object and mode of knowledge" (p. 13). Paradigm, furthermore, is preferable to a wider notion of an organised body of questions and answers. It should also neatly signal the dependence of understanding literary discourse, while including the idea of knowledge and a subject/object relationship. Identifying a literary paradigm, therefore, requires a search for a unified conception of its object, a subject that is posed in correspondence to this object, and a method which mediates between the object and the subject and intervenes to bring the object and the subject into a relation of knowledge. The first element of the literary paradigm is as an object of study, which relies upon an inherited tradition, in which the literary text is held to be self-sufficient, and a complete 
expression of an equally self-originating author, or something fixed once and for all in language as the peculiar passion of the public. This is, however, a paradox of the claimed universal assumption, since the traditional reliance of literary theory on the empiricist epistemology germinates the 'politics of theory'. A universal truth of a literary text that relies on an empiricist epistemology, thus a unified literary theory is difficult to reach.

The second element, a 'method of reading', has delimited for itself a particular field that takes literature to be a high cultural or canonical tradition by excluding other literatures or forms of art (Easthope, 1991). Referring to method as 'the modernist reading' or 'the modernist literary aesthetic', Easthope explains that "the method of literary study reproduces the category of the aesthetic because it seeks to make subject and object transparent to each other - the modernist reading assumes the text signifies all over and that every object feature of language bears subjective import" (p. 13). This kind of reading consists of the 'protocol of the literary study' and the method 'working behind its back'. By displacing a tradition of mixing impressionism and scholarly research, modernist reading establishes hegemony by instituting a fashion of reading that requires a detailed serious theme, an interaction between an idea and structure.

In this sense, modernist reading, which had stood as a paradigm for fifty years, had lost its ground, and the exasperated literary critics who follow it exclaim, 'Why can't we get away from all this theory and just study literature as literature?', forgetting that the concept of literature itself has certain essential features that cannot be bypassed. The modernist reading assumption presumes that a text has one important theme that needs to be revealed, and if all aspects of the text can be shown to interact, their thematic significance is taken to be important. The underlining assumption of modernism is based on a 'a sense of lost humanity and civilisation and embodied of contradictions and paradoxes, embraced multiple features of modern sensibility" (Ciaffaroni, nd). T.S. Eliot (1923) for example, comments on Joyce's technique as "a way of controlling, of ordering, of giving a shape and a significance to the immense panorama of futility and anarchy which is contemporary history.... It is, I seriously believe, a step toward making the modern world possible for art."

Institutionally, or through the 'ideological state apparatus' (Althusser, 1970) [emphasis added], the establishment of literary studies at higher education institutions exercises a humanist hegemony (Gramsci, 1971) where the Arnoldian "best self is supposed to be imaginatively caught up into a larger experience beyond the bounds of class, locality, time or country" (Easthope, 1991, p. 18). The humanist education of a scholar, a gentleman, and a Christian, extending from the Renaissance revival to late bourgeois flowering, seems not to work in contemporary literary or cultural studies. In this regard, Hough (quoted in Easthope, 1991, p. 18), commenting on the status of literary studies in the mid-1960s, concludes, "the old Christian-humanist ideal is looking remarkably worn and battered; and with its erosion the inherited pattern of literary education has fallen into a dismal confusion. For a literary education is concerned with personal values; it does not really stand for anything, has no aim or purpose, without some ideal of personality behind it" (p. 97).

The emergence of theory in literary studies is another symptom of a crisis in the field. Guillory (1993) contends that theory in itself is a 'pre-eminent' and 'deconstructive' form that resurrected the discipline of rhetoric, which acted as a means of redefining literature. It also functions as an authoritative way of extending the properties of literariness to particular texts and denying them to others. The moment of theory, for Guillory, is a crisis in the 'market of value' that is occasioned by the emergence of a 'professional-managerial class'. It is a crisis that "calls forth a redefinition of literature itself, a redefinition which incorporates as a new aspect of literary study the 'technical' quality of the knowledge valued by the professional-managerial class. Needless to say, the emergence of theory is the symptom of a problem which theory itself could not solve" (p. xii).

\section{From literature to cultural studies}

Culture as a 'conversation' is a well established maxim in cultural studies. Such a perspective has developed, amongst practitioners and theorists, emphasizing literature as a text of culture, with values and beliefs central to a community of language users, and typically taught through education systems and educational institutions (Easthope, 1991). In other words, the paradigm shift from literary study to cultural study occurs through considering the context of the text, in a way that examines the social, cultural, and political manifestations of the literary text. This shift has been intensified through the emergence of a new class of radical criticism, such as feminism, post-structuralism, psychoanalysis, and post-colonialism, that scrutinise the role of the text in social representation.

In his challenge to the paradigm of literary studies, Williams $(1958,1961)$ has contributed to the emergence of the discipline of cultural studies. He critiqued the current literary studies when they were heavily directed towards a reassessment of aesthetics. Instead, he deepens the practice of literary textual analysis by broadening its scope to include diverse forms of cultural productions beyond the canonical literary text. Thus, he opens the way for new modes of analysis that are associated with contemporary cultural studies; he challenges the orthodoxies of high culture by deconstructing the opposition between high and low culture that used to be the structuring principle of English studies. Williams asserts that cultural studies must be prepared to go beyond literary texts and include every form of signifying practice as a valid object if it is to count as a serious discourse of knowledge. Cultural studies, Williams (1961) explains that cultural studies must establish democratic principles where the discourses of all members of a society should be acknowledged, not just those of the educated elite. In this view, the study of literature has become a cultural phenomenon or a 'discursive practice' that takes up culture as its backdrop.

By broadening areas of critique beyond the realm of aesthetics, and through affiliation with other disciplines, such as radical politics, this generation of critics concerned themselves with social and cultural issues such as gender, race, and oppression, all of which contributed to the shift of (in?) the field. The underlying assumption of these projects is the 
belief that if literary study marks off its field from other disciplines by separating literary study from its cultural and social contexts, it segregates a specialised domain of the aesthetic from the rest of life (Easthope, 1991). Post-colonial critics, for example, view the study of literature as a densely political and cultural phenomenon, and a practice that profoundly serves and embraces nationalism (Ashcroft et al., 1989, 1995, 1999, 2000). To achieve a better understanding of the notion of literature, a more comprehensive approach is required: an approach that acknowledges the complicity between literature and culture and how they are intermingled in a way that serves an immediate contextual background. Therefore, the analysis of literature in the context of cultural studies, a thesis I adopt in this study, marks a profound understanding of the concept of literature as well as a comprehensive approach to literary meanings.

\section{The post-colonial turn}

Humanist literary studies have long been resistant to the idea that literature has anything to do with politics. The underlining assumptions of this belief is that literature is either too subjective, individual, and personal, or too universal and transcendent to be blighted. Accordingly, the relationship between colonialism and literature was not, until the last decades of the twentieth century, dealt with by literary criticism (Loomba, 1998, 2005). Said's (1978, 1983, 1985, 1990, 1993, 1994, 1995, 2001) work, however, primarily dependant on western literary texts for analysing colonial discourse, has opened a way for the majority of literary critics to bypass the humanist orthodoxies of literary studies. In his analyses, Said shows how both language and culture are implicated in constructing the binary of a European 'self' and a non-European 'other', which have been exploited as a part of the creation of colonial authority. Nonetheless, Said (2004) re-examines the notion of humanism in the context of $21^{\text {st }}$ century academic and political spheres to elevate the damage brought to the study of humanism by both structuralists and poststructuralists. He reconceptualises humanism as open, democratic and secular approach: It is a "process of unending disclosure, discovery, self-criticism, and liberation". The heart of humanism is critique, which "is a form of democratic freedom and as a continuous practice of questioning and of accumulating knowledge that is open to ... the constituent historical realities of the post-Cold War world" (p.47). He argues that in order to make sense of the text, we must not only read, but reread texts. In this respect, he distinguished himself from Foucault's views of knowledge as subservient to power. He concludes that representations evolve in an essential 'worldliness' where power, position and interest are inextricably intertwined and revolving. While we cannot achieve total understanding of words and texts, we can achieve an adequately critical understanding "that may never be completed but can certainly be provisionally affirmed" (p.67). 'Critical receptivity" includes reflection, research, inquiry, dismantling, unpacking, documentation, and refutation, and its open character is consistent with Said's view of history as being incomplete and ongoing. The mind of a humanist demystifies and makes transparent the meaning and origin of words and the ideas that they carry; the humanist is a questioner, one who cultivates a sense of multiple worlds and complex traditions, embraces catholic inclusiveness rather than elitist exclusiveness, and experiences, as both reader and intellectual, a sense of belonging and detachment with respect to the world of the text. Old humanism, according to Said, was Eurocentric and nationalist such that it failed to have a genuine cosmopolitan, internationalist perspective and an intellectual curiosity that a new humanism should have that are crucial to engaging with an increasingly globalised world of the $21^{\text {st }}$ century.

The pivotal role of literature in both colonial and anti-colonial discourses has played an important role in the works of contemporary literary studies, which has placed literary studies in a wider social and cultural position for the purpose of analysing and interrogating its universal value and pointing out its crucial role in cultural hegemony, colonialism, race, gender discourses, among others. Specifically, attention to the relationship between literature and colonialism has recently provoked serious reconsiderations of the traditional image of literature as a moral project calling for humanist and universalistic ideas of literary tradition. Post-colonial critics continue to investigate how the 'apolitical' literatures of the West have contributed to the naturalisation of colonialist myths or ideologies and how a variety of discourses of empire and race have formed mutually reinforcing and complementary chains of the signifying system. By emphasising the differences and variations among individual texts, they attempt to delineate an underlying commonality and continuity in Western representations of racial and cultural 'alterity' (Said, 1994).

Traditionally, the study of English literature was a means for securing England's imperial mission, and has, altered the way English texts are read and analysed. Said (1993), for example, suggests that "[w]ithout empire, I would go so far as saying, there is no European novel as we know it, and indeed if we study the impulses giving rise to it, we shall see the far from accidental convergence between the patterns of narrative authority constitutive of the novel on the one hand, and, on the other, a complex ideological configuration underlying the tendency to imperialism" (p. 69-70). Spivak (1985) suggests that "it should not be possible to read nineteenth-century British literature without remembering that imperialism, understood as England's social mission, was a crucial part of the cultural representation of England to the English" (p. 243). Similarly, Loomba (1998) declares that "no work of fiction written during that period, no matter how inward-looking, esoteric or apolitical it announces itself to be, can remain uninflected by colonial cadences" (p. 73).

Post-colonial review of English literature puts under scrutiny the cultural representations of both the colonial and colonised figures (Said, 1978, 1993, 1995; Achebe, 1977; Bhabha, 1990, 1994, 1996; Loomba, 1998; Ashcroft et al., 1989, 1999, Achebe, 2003). In this respect, post-colonial literary studies have played a key role in reviewing traditional orthodoxies of literary and cultural studies which have attempted to impart Western values to the natives, and to maintain colonial rule by constructing European culture as superior and as a measure of human values.

The Africans, for example, were considered bestial because medieval European religious beliefs associated blackness with filth and dirt. Since whiteness has been central to European views of beauty, on first encounter, black people were 
automatically regarded as ugly. In England, such cross-cultural encounters and distinctions were not only features of travel tales, but literary writings, which appeared to be inward looking, and whether dealing with private or public concerns, were also invested in the epistemologies that fuelled England's overseas expansion. Loomba contends that "colonial contact is not just 'reflected' in the language or imagery of literary texts, [...] but [is] a central aspect of what these texts have to say about identity, relationships and culture" (Loomba, 1998, p. 65).

Furthermore, literary and cultural practices embody cross-cultural interactions and hybridity. Loomba (1998) shows that throughout the medieval and early modern periods, there were notable European appropriations of non-European texts and traditions, particularly Arabic texts. European literature is not simply written in Europe for Europeans, but is produced within the context of the history of interactions going back to antiquity. As such, "the syncretic nature of literary texts or their ideological complexities should not lead to the conclusion that they are somehow 'above' historical and political processes. Rather, we can see how literary texts, both through what they say and in the process of their writing, are central to colonial history" (p. 67). Although disciplines like comparative literature have acknowledged the profound interaction of various cultures and literatures, this interaction is hierarchically organised. The central assumption was that "Europe and the United States together were the centre of the world, not simply by virtue of their political positions, but also because their literatures were the ones most worth studying" (Said, 1995, p. 22).

Post-colonial analysis of colonial discourse exceeds the boundaries of those texts carrying the label 'literature', and extends its study to all cultural productions of the colonial authorities. The underlying assumption of such a tradition or mode of analysis, aiming to unfold imperialist discourse, applicable to both literary and non-literary works, is that colonial authorities had exploited all available ways to normalise their knowledge about the colonised subject (Ashcroft et al., 1989). Loomba (1998) suggests that to understand colonial knowledge it is vital to avoid separating literary from other writings. She believes that non-literary texts such as newspaper stories, government records and reports, memories, journals, historical tracts or political writings are equally open to analysis of their rhetorical strategies and narratives devices. Such works, Loomba proceeds, "are not necessarily 'objective' but represent their version of reality for specific readers. So not only are literary texts useful for analysing colonial discourse, but the tools of literary analysis can also be used for understanding the other 'texts' of empire” (p. 72). In a similar vein, Spivak (1988) endorses Foucault's argument when she suggests that "to make visible the unseen can also mean a change of level, addressing oneself to a layer of material which hitherto had no pertinence for history and which had not been recognised as having any moral, aesthetic or historical value" (p. 285).

Post-colonial literary critics have examined the hegemonic role of the study of literature in post-colonial settings. Ashcroft et al. (1989) argue that the continuing engagement with the imperial experience in post-colonial societies is a sign of cultural hegemony that persists in these contexts. Although the dominant colonial powers of the nineteenth century have been relegated to some spheres, such as politics and economics, "through the English literary canon, the body of British texts which all too frequently still acts as a touchstone of taste and value, [...] continues to dominate cultural production in much of the post-colonial world" (p. 7). This cultural hegemony, according to Ashcroft et al., has been maintained through canonical assumptions about literary activities that see other literatures as 'isolated national off-shoots' of the tradition of English literature. Such assumptions relegate literature written by non-English writers to minor and subordinate positions. Jameson (1986), for example, argues that 'Third World' Literatures are not popular in the western world because they are self-closed around ethnocentrism and nationalism, or, in the best cases, revolving around the coloniser/colonised relationship. While the western scholars, who are familiar with a history of 'open' philosophy and thought find the western 'canon' closer and 'familiar' to them. He reasons "indeed our want of sympathy for these often unmodern third-world texts is itself frequently but a disguise for some deeper fear of the affluent about the way people actually live on other parts of the world" (p. 66). Within such a reductionist ad stereotypical views, which mainly draw on early world or post-colonial literatures during the era of colonialism or in its aftermath (see below), these literatures are rendered alien or unworthy to the taste of western reader. Additionally, Jameson inadequate analysis stems from the fact that he draws on a specific subset of by authors who keenly interested in the Western canon, who consciously sought to construct works of fiction that would interact with that canon as national allegories. Additionally, Jameson argues: "we sense, between ourselves and this alien text, the presence of another reader, of the Other reader, for whom a narrative, which strikes us as conventional or naïve, has a freshness of information and a social interest that cannot share" (p. 66). Indeed, despite of Jameson's sympathetic tone one can observe that it obscures more than it reveals. On the one hand, while the English literary tradition per se entails humanistic value, other world literature remains alien and self-enclosed, and, by virtue of this, they cannot qualify as universal text beyond their immediate contexts. The conscious use of 'other', on the other hand, explicitly evokes the notions of 'self/other' binaries; whereas the 'self' is the norm, familiar and comprehensible, the 'other' remains the deviation, unfamiliar and incomprehensible as well as being a 'periphery' to something 'original'.

In short, the study of literature has become more widely recognised as essential for cultural understanding of the historical context that produces and embraces it. Although the purpose is extremely different, the post-colonial turn regarding literary or cultural analysis is in accord with those early traditions in their inconsistency in determining the boundaries around what could be taken up as paradigm of literary studies. The post-colonial literary tradition, thus, consolidates the idea of interconnectedness between culture and literature and how the category of literature has become a sort of cultural artefact that conveys particular messages or reflects 'appropriate' social and cultural beliefs. 


\section{Literary value-judgement}

This section discusses the following questions: what is literary value? How are certain literary works made popular? Who chooses them and decides upon their popularity? Do students choose what they read? Do they make sense of what someone chooses for them? Specific answers are not easy to reach, either to these questions or to the larger issue of literary value. General understanding, however, might be attainable. In response to these questions, I argue that 'the art of persuasion' is a power of manipulation, coercion, and intimidation that makes people consent to, accept, and appreciate what others consider to be of 'proper value.

To understand the concept of value-judgement in general and literary value-judgement in particular, I build on Bourdieu's (1984) argument about 'cultural tastes' which are group-specific in nature where certain members of a given social class acquire a 'habitus' (i.e. a set of schemes of perception, appreciation and action) which coordinates their cultural preferences at conscious and unconscious levels. The effect of the habitus is that "all the practices and products of a given agent are objectively harmonised among themselves, without any deliberate pursuit of coherence, and objectively orchestrated, without any conscious concertation, with those of all members of the same class" (p. 172). Taste is not an innate faculty, but is determined by a gatekeeper who owns the capacity of 'decoding' and 'deciphering' the meaning of aesthetics, which presupposes practical or explicit mastery of cipher or code. Therefore Bourdieu deems

a work of art has meaning and interest only for someone who possesses the cultural competence, that is, the code into which it is encoded. The conscious or unconscious implementation of explicit or implicit schemes of perception and appreciation which constitutes the pictorial or musical culture is the hidden condition for recognising the styles characteristics of a period, a school or an author, and, more generally, for the familiarity with the internal logic of works that aesthetic enjoyment presupposes (p. XX).

According to Bourdieu, the encounter with literary work is not 'love of a first sight', but the 'art-lover's pleasure' presupposes the act of cognition, a decoding operation that requires the implementation of a cognitive acquirement, a 'cultural code'. This is, however, acquired through a legitimate system that is a product of history and culture and is reproduced by education. This is how artistic perception is accepted and legitimatised. As such, the aesthetic disposition becomes a form rather than a function: legitimate works of art are necessarily and increasingly historical, differential, relational, and attentive to the deviations that make styles. The historical culture functions as a principle of pertinence that enables one to identify all the distinctive features of the work.

Investigations in the fields of literary value-judgement and aesthetics have been advanced by Bourdieu's argument. Research has investigated a plethora of related areas of literary-value judgement. These areas include the social foundations and effects of literary criticism, the activities of critics, the institutional nature of literary classification, literary productions, and publishing (Janssen, 1988, 1997; Verdaasdonk, 1983, 1994, 2001; Guillory, 1993; Rusch, 1999; Bauman, 2001; Hunter, 2001). Bauman (2001), for example, reports three factors in explaining public acceptance and appreciation of cultural products as art. The first factor is the 'changing opportunity space' which is brought about by social change outside the art world. According to Maggio (quoted in Bauman, p. 504), cultural genre succeeds in gaining recognition as art depending on the shape of 'opportunity space', which he defines as the appearance of 'competitors', 'substitutes', and the formation of a pool of high status 'patrons' who can act as sponsors. Besides, a cultural product's 'associations' that have a high status can help to legitimate the product as art. "The second factor crucial to explaining the creation of artistic status is the institutionalisation of resources and practices of production and consumption by members within the art world" ( $p$. 504), I discuss this factor in detail below. The third factor is a legitimating ideology. Ferguson (quoted in Bauman, p. 405) argues that it is through the texts that a field of cultural production is established and cultural product is transformed into an 'intellectual phenomenon'. Therefore, "the development of a field-specific set of aesthetic principles provides a rationale for accepting the definition of a cultural product as art and offers analyses for particular products" (p. 505).

Verdaasdonk, in a series of studies (1985, and 2001), has analysed the formation of literary careers and reputations within the field of cultural production. His studies are generally empirically oriented and provide a basis on which to question how institutional networks, particularly literary criticism, propagate their own activities, and how they, together with other connoisseurs, function within a specific social framework in judging literary works. He focuses on critics' and reviewers' behaviour in judging literary works as largely an institutional practice, which reflects a stereotypical and persistent ideology that is shaped by 'institutional' benchmarks and standards. Although both members of literary institutions and non-professional readers usually perceive their involvement with literature as a highly individual affair, they are regulated by the norms, ideas and practices that prevail within their institutional environment. In her critique of the institutional practices of literary reviews and criticism, Janssen (1997) contends that these activities emphasise a 'class norm', either 'pure' or 'internal (artistic)'. In so doing, reviewers perceive themselves to be 'autonomous', they ignore a variety of social factors that determine critical activities and wrongly suggest that the collective actions of various categories of critics result in an 'objective' assessment of the distinct value of literary works. In fact, institutional practice as such performs a model of aesthetic and value-judgement hegemony, in the ways critics bear the responsibility of deciding about literary work and holding an intermediate position between the literary work and its ordinary audience.

Moreover, literary criticism, adopts certain codes of practice for instigating forms of hegemony and 'cultural capital' when the question of literary appreciation is considered. It has been argued that no specific capacity or procedure enables a critic to identify textual properties in an unequivocal way. Furthermore, it is difficult to establish empirical or 
logical connections between the apparently certain properties of a text and a particular value-judgement (Van Rees quoted in Janssen, 1997, p.277). Despite the fact that they cannot identify a reliable instrument for grounding critical statements or establishing harmony between diverse conceptions of literature, critics and reviewers often reach an agreement on which literary works deserve their attention. This consensus is often taken by critics as proof of their capacity to assess literary quality in an intersubjective way, especially when they reach an agreement regarding a particular work. Because they write their reviews independently of one another, critics are seen as 'reliable' by the outer world and normal readers. Although this behaviour seems neutral or objective and to a certain degree independent, it is not possible to overlook the fact that critics and reviewers take due note of each other's achievements (Janssen, 1997).

Additionally, societal value orientations consist of two pairs of basic values: a) values of truth and righteousness, and b) beauty and usefulness. These are pertinent to cultural institutions that consist of many sub-institutions. Educational, religious, and economic institutions together with media are among the most influential institutions that shape individuals' value orientations. Educational institutions, in particular, play a major role in shaping students' understanding of value judgement since schools create a coherent, stable, unified system to shape students' artistic taste (Rosengren, 1998). Educational institutions, thus, become strict custodians or 'sentinels' that channel students' orientation and sense of values (ibid). Hunter (2001) contends: "we train all our young people to read by the way of [canonical] writers; they acquire most of their sense of literary value and aesthetic taste from these writings" (p.7).

Hunter (2001) argues that value-judgement is not impulsive or strategy-free, but is channelled by a rationale or purpose for the choice. If, for instance, some people are asked to list the five most valuable writers in their life, they will probably wish to ask what is the list for? If for education, the lists would be highly consistent and would mainly represent highly authoritative and canonised works. If it is for revealing their inner lives, it would be much more varied, though some consistency might exist depending on their age or cultural background. And if it is for reaching out to another community, they might need to demonstrate in their list what best conveys their national values. In sum, when institutions channel not only what should be valued, but also teach how to value what has been chosen, students' sense of values and value-judgements becomes a product of a tradition of persuasion and hegemony, rather than an individual-specific practice. Jordanian English departments oppress students by adopting a monolithic tradition that is not only alien to students' cultural backgrounds, but is also old fashioned, and in many cases governed by ideological assumptions (Abu-Shomar, 2012). This is oppressive because aesthetic and literary taste, as far as value-judgement is concerned, can be left to individuals to make for themselves.

\section{The story of 'English' literature}

Tracking the development of English literature requires a profound understanding of the socio-political changes that took place as it developed over history. In my analysis and reading of the corpus of the English literature, I highlight the multitude of the contexts to emphasise the multiplicity of the social settings in which English literature has developed. I move between geography, time, and social actions such as cultural debates, politics, resistance, and institutional practices to show how English literature reached its current status. The historical approach used in this section allows for a clear explanation of the issues that preoccupy literary studies. For this particular purpose of the key argument (literature and ideology), I have devised a sort of thematic approach through which certain themes serve as divisionary turning points of the eras under exploration.

\subsection{Theme One: the philistines need action}

The modern sense of English literature began to develop around the eighteenth century; an era that witnessed major social and intellectual changes. In this era England was dealing with tensions among the social classes that developed due to the civil war in the previous century. Notions of reason, nature, order, and property were epitomised in art as key concepts for the middle class. A need, therefore, had emerged to incorporate this increasingly powerful, but rather spiritually 'raw' middle class into unity with the aristocracy. Literature, therefore, gained a new importance as it could diffuse polite manners, habits of good taste, and common cultural standards to its readers. To achieve this aim, "a whole set of ideological institutions: periodicals, coffee houses, social and aesthetic treatises, sermons, classical translations, guidebooks to manners and morals" were established (Eagleton, 1996, p. 15). In response to these changes, a literary movement that is now known as the 'Romantic Period' was in fact a signifying concept of human creativity that is radically at odds with the utilitarian ideology of the early industrial capitalist England. This movement narrowed the category of literature to what is called 'creative' or 'imaginative' work, which later in the 'Romantic Period' became synonymous with 'imaginative' (p. 16).

This period, Eagleton proceeds, was one of revolution when the feudalist regimes were overthrown by middle-class agitation. This revolution uprooted the whole society in England converting human life into wage-slavery, and enforced the notions of the labour-process that transformed everything into a commodity on the open market. In the face of such 'philistine' materialism, literature countered those rationalist or empiricist ideologies enslaved by fact. It was therefore no accident that aestheticism, or the philosophy of art, developed around this period. Aesthetics underline the assumption that art is an unchanging object, or an isolatable experience of beauty; this assumption alienates art from social life and makes the whole idea of 'creative' useless, and an end in itself, loftily displaced from everyday life. Art was extricated from its material practices, social and ideological meanings, and historical difference and given it the status of a solitary fetish.

Thus, literary work came to be seen as a mysterious organic unity, in contrast to the fragmented individualism of the capitalist marketplace; "the word 'poetry', then, no longer refers to a technical mode of writing: it has deep social, 
political and philosophical implications, and at the sound of it the ruling class might quite literally reach for its gun" (Eagleton, 2008, p. 17). The eighteenth-century conceptualisation of literature was not limited to today's categories of 'creative' or 'imaginative' writings. Inclusions and exclusions of certain works from the realm of literature were not dependent on their intrinsic nature. What counted was a wider social, cultural, or perhaps political tradition at certain moments of history (ibid). Reviewing the historical tradition of what constitutes a literary work?, Eagleton (1996) concludes in the eighteenth-century literature in England

meant the whole body of valued writing in society: philosophy, history, essays and letters as well as poems. What makes a text 'literary' was [...] whether it conformed to certain standards of 'polite letters'. The criteria of what counted as literature, in other words, were frankly ideological: writing which embodied the values and 'tastes' of particular social class (p. 15) [emphasis added].

\subsection{Theme Two: A salvation enterprise}

In the 'Victorian Period', religion progressively ceased to provide social solidarity, which gave literature the responsibility of carrying this ideological role. This notion became more evident in the middle of the period when it was clear that religion was no longer winning the hearts and minds of the 'masses'; scientific discovery and social change had caused the collapse of its authority. The Victorian ruling class was agitated, since religion had been an effective tool of ideological control. They turned to literature to fill this void as it had become "affective and experiential, entwining itself with the deepest unconscious roots of the human subject; and any social ideology which is unable to engage with such deep-seated a-rational fears and needs" (ibid, p. 20).

Therefore, literature was seen as a secular version of religious writings that took upon itself the task of educating people, and was grounded in the idea that "literature, in the meaning of the word we have inherited, is an ideology" (ibid, p. 19) [emphasis in text].

Additionally, institutional practice in this era embodied the notion of Arnold's well-known formula of literature as 'the best culture of the nation'. F. R. Leavis, a founder of literary studies in the UK, and an inheritor of Arnold's school of thought fashioned the study of literature not as a subject, but as a civilising pursuit; the spiritual essence of the social formation. Leavis staked out a special position within literary study that explicitly distinguished between literature and non-literature (Easthope, 1991). In defining his position of what counts as literary study, Leavis, following Arnold's line of thinking as quoted in Easthope, writes:

in any period, it is upon a very small minority that discerning appreciation of the art and literature depends ... upon this minority depends our power of profiting by the finest human experience of the past [...] Upon them depends the implicit standards that order the finer living of an age, the sense that this is worth more than that $[\ldots]$ (p. 3-4).

The idea of the classics or the best of the nations' production was rooted in the way the Victorian upper classes reacted to the evolution of the lower classes. The upper classes had beliefs that they regarded as reasoned positions, rather than ideological ones. They believed that literature could convey timeless truths and could distract the lower classes from their immediate commitments and nurture in them a spirit of tolerance and generosity.

Although the early decades of the twentieth century witnessed the formation of a radical understanding of literature and literary studies, the orthodox literary tradition was dramatically changed towards the second half of the century by the new liberal school of thought. Once an undergraduate of the very English faculty Leavis and his radical colleagues did much to create, Eagleton launched an opposition to their tradition by defining them as the 'inescapably elitist', and accusing them of ignoring the capacities of those not fortunate enough to have read English at Cambridge (Easthope, 1991). In fact Eagleton, due to the wide audience for his books, is another example of the fluidity and dynamism of the concept of literature that reflects part of the general taste of society.

\subsection{Theme Three: The 'masses'; do they belong?}

John Carey's The Intellectuals and the Masses (1992) provides a thorough analysis of literary intellectuals' reaction and hostility towards the new phenomenon referred to as 'mass culture', which helps explain how canonised literature is an instrument of hegemony and social control, and how it was and is used in post-colonial educational settings to exclude and control the majority in the interests of a small, privileged, Eurocentric minority.

The 'mass', according to Carey, is a metaphor that denies human status to the majority of people. In order to do this, modernist literary intellectuals have configured the image of the 'mass' and have seen them as a sickness, a threat, and a danger to society; an image that changed according to the wishes of the imaginer. Images, such as 'overcrowding', 'overpopulation', and 'hyper democracy', for instance, were believed to threaten civilised societies. Ortega contended that if we wish to observe the mass, there is no need for us to wait until the whole mass comes along: "in the presence of one individual we can decide whether he is 'mass' or not" (quoted in Carey, 1992 p. 23). The invented identities for the 'masses' were all derogatory and provided the intellectuals with a defence against the unidentifiable 'other'. Their aim is to segregate the intellectual from the 'other mass', and to acquire the means to practice power and control over them.

In The Revolt of the 'Masses', Ortega (quoted in Carey, 1992 p.3) expressed his concerns about overcrowding and hyper democracy and sees the crowd taking possession of places which were created by civilisation for the best people, and fears if the 'masses' acquire social power, civilisation would be in grave danger. "Less drastic, but more practical, was the suggestion that the mass should be prevented from learning to read so that the intellectual could dominate 
written culture" (Carey, 1992, p. 15). D. H. Lawrence adopted this idea and argued, "let all schools be closed at once, the great mass of humanity should never learn to read and write" (quoted in Carey, p. 15).

Reading was a real concern to those intellectuals who understood literacy to be the difference between the nineteenthcentury 'mob' and the twentieth-century 'mass'. George Bernard Show asserted that 'the Education Act of 1871 was producing readers who had never before bought books, nor could have read them if they had" (quoted in Carey, 1992, p. 6). T. S. Eliot and Leavis, among others, saw in the spread of books and growth of colleges an evil effect of democracy. They called for a revival of the 'monastic' teaching order. Students, according to them, should return to the cloister where they would be "uncontaminated by the deluge of barbarism out side" (quoted in Carey p. 15).

In the realm of art, they sought to divide the world into two opposites: "those who can understand it and those who cannot" (Ortega quoted in Carey, p. 17). Modern art(s), should not, therefore, be made popular; they act like a social agent that segregates the elite from the 'shapeless masses'. This idea was welcomed by intellectuals since for an aristocratic elite, modern art compels the 'masses' to recognise themselves for what they are: the 'inert matter of historical order'. It also helps the privileged minority to distinguish themselves from the 'drab mass' of society. In reaction to 'mass values', they brought into being the theory of the 'avant-garde', which assumes that, in literature and art, the 'mass' is always wrong. Thus, "what is truly meritorious in art is seen as the prerogative of a minority, the intellectuals, and the significance of this minority is reckoned to be directly proportionate to its ability to outrage and puzzle the mass" (p. 18). According to Ortega, the 'mass' is incapable of achieving 'purely aesthetic' sense because the 'masses' seek human interest in art and are caught by the passion and pain of the poet. These preferences, he contends, prove the inferiority of the 'mass' because "grieving and rejoicing at such human destinies as a work of art presents or narrates is a very different thing from true artistic pleasure", and the preoccupation with the human content is "incompatible with aesthetic enjoyment proper" (p. 19).

The process of alienating the 'mass' was problematic, but placing art beyond the reach of the 'mass' was a deliberate aim for many intellectuals. T. S. Eliot, for instance, adopted this desire, evident in both his writings and his remarks. In his writings, he deliberately sought to alienate the 'mass' audience by veiling his syntax, alienating his images, and introducing indefiniteness in order to exclude many people from his readership. In his decrees, he once asserted: "poets in our civilisation, as it exists at present, must be difficult" (quoted in Carey, p. 23).

\subsection{Theme Four: The Empire; A 'textual exercise'}

At the turn of the twentieth century the British imperial power covered vast areas of the world. This era witnessed both the greatest expansion of the British Empire and its demise. It sought to dominate other parts of the world through political, military, and cultural domination; this explicit ideology of moral, cultural, and racial supremacy that backed its ventures was a distinctive mark of European colonialist missions (McLeod 2000). In order to achieve its imperial project, it used a set of ideas, language, knowledge, and discourse along with military and political forces. At the heart of this set is literature, since it is central to the formation of any culture by occupying a pivotal place in societies and through its crucial role in normalising, defending, stereotyping, and nurturing beliefs and practices (Ashcroft et al., 1989).

Since the early days of colonisation, literature has underpinned efforts to interpret other people and their lands, offering the home audience a special way of thinking about exploration, conquest, national valour, and new colonial acquisition. Boehmer (2005) traces and contextualises colonial and post-colonial literatures in English. According to her, the text during the Empire was 'a vehicle of imperial authority' and it symbolised 'the act of taking and possession':

Present-day readers, anyway, experience empire textually, through the medium of nineteenth- and twentieth- century novels and periodicals, travel writings, [and] scraps of doggerel (p. 14).

She further asserts that "imperialism and the novel fortified each other to such a degree that it is impossible ... to read one without in some way dealing with the other" (p. 71). Said (1993) insists that the nineteenth-century English novel supports colonial occupation, views which were realised in Rudyard Kipling and Joseph Conrad, but were supported in Jane Austen and William Makepeace Thackeray. For Said, the entire canon of nineteenth-century English novels is culpable in supporting the ideologies of Empire in that the novels "stress the continuing existence (as opposed to revolutionary overturning) of England. Moreover, they never advocate giving up colonies, but take the long-range view that since they fall within the orbit of British dominance, that dominance is a sort of norm, and thus conserved along with the colonies" (p. 74-5).

The business of colonisation was a gamble and an experiment, with lives, funds, and above all with meanings: "They transferred familiar metaphors, which are themselves already bridging devices, which carry meaning across, to unfamiliar and unlikely contexts" (p. 15). Thus, colonialism was a metaphoric undertaking, in which classifications and codes were imported from the homeland and matched to people and cultures that were entirely different.

In this sense, writing under the empire was itinerant and adaptive with a primary distinguishing feature that it was activating imperialist energies and focusing on colonial myths. Boehmer refers to such texts as 'the travelling metaphor', which formed an essential constitutive element of an intensely imagined colonial system. These metaphors were ways of 'mapping the known to the unknown', and 'mingling into that unknown meanings derived from a very different environment'. The distinctive feature of colonialist literature under the empire is the tendency to construct diachronic connections between different cultures. This inclination, which was facilitated by the horizontal distinctions that separated Europeans from others across the imperial world, was a function of imperialist superiority. Nonetheless, such a cross-cultural encounter was a particularly problematic one for colonisers who had to devise terms not only with 
the imported culture, but also with the indigenous cultures. Brydon and Tiffin (1993) explain this process as "simultaneously a confession and denial of guilt - an identification and a usurpation - ensues when white writers choose native people as literary material" (p. 127).

\subsection{Theme Five: Aftermath}

Colonialist literature with its exploratory and expansionist attitudes proclaims cultural superiority and rightness and was not to last. Conrad's dark tales and Kipling's brooding hymn Recessional, for instance, were prescient in their foreboding. In contrast to mid-Victorian literature, twentieth-century English literature is distinguished by a large-scale disintegration of old absolutes. Novelists such as Virginia Woolf, E. M. Forster, and George Orwell featured an unmistakable new uncertainty, and the note of questioning is present whether they address home or colonial subjects. Yet, the imperial retreat of this period contributed to and reinforced their uncertainty. Disillusion and retreat on the side of the empire were accompanied by resistance and reconstruction on the part of those who spoke for the colonised; oppositional movements of resistance and self-affirmation began to emerge in the Britain's colonial territories. Colonised elites, though embattled, have begun to initiate cultural revivals and raising their voices in protest of imperial power. Literary responses to the empire and the colonial authorities, however, followed diverse trajectories that ranged between mimicry, replication, resistance, and opposition (Boehmer, 2005). In a similar vein, building on Freudian psychoanalysis, Gilroy (2005) use the concept of melancholia to argue that post-colonial condition after the demise of Britain as an-imperial power is shaped by 'planetary humanism' that is different from globalisation. For him, planetary "suggests both contingency and movement, It specifies a smaller scale than the global, which transmits all the triumphalism and complacency of ever-expanding imperial universals" (p. xv). Exemplifying on post-colonial melancholia, Gilroy draws on the comic television figure of Ali G who is a British Jamaican; "Ali G character was a white Jew pretending to be black, a white Jew pretending to be a white pretending to be black, a white Jew pretending to be an Asian pretending to be black, and so on" (pp. 70-71).

\subsection{Theme Six: The mimics}

Neither the colonisers nor the colonised were homogeneous categories (Bhabha, 1994). Although it is expected that colonised subjects would resist colonial rule, countless colonised elites parroted the lines of their masters (Loomba, 1998). Fanon remarked that the colonised man breathed the 'appeal of Europe like pure air' (quoted in Boehmer, 2005, p. 110). They "adopted the persona of the enlightened English gentleman - more correct, more colonialist, more English in fact than the real item" (Boehmer, 2005, p. 111).

In the realm of literature, the idea of mimicry is a crucial part of the nature of literary works produced by colonised elites under the empire. Through their writings, the colonised elites performed a vital role that seemed to place them in a better position in the formula of colonialism. They assume that colonial powers were to bring them income, status, and the possibility of sharing in power, but they were denied such positions.

Mimicry is an act that is never very far from 'mockery' (Bhabha, 1994). It does not matter how far colonised mimics had attempted to raise their status within the imperial system, imperial ideology marked them, and their arts, as inferior. At a time when the artistic views of the elite might have been at best included in the colonial culture, they were never seen as participants of that culture (Boehmer, 2005). Recently, post-colonial theorists have analysed such behaviour. As a process through which the colonised subject is reproduced as 'almost the same, but not quite', mimicry is a process of copying the colonising culture, behaviour, manners, and values, which contains mockery, ambivalence, and thus a certain menace (Bhabha, 1994). The peripheral replications of late European humanism and modernist literary traditions, for example, has positioned them between diametrically different cultural worlds, though being able to borrow from several traditions, yet belonging to no one. Boehmer (2005) argues that "while the new colonial writers stood to learn much from the techniques of dislocation which distinguished the modernist avant-garde, for expatriate and colonised artists, modernist urban reality correlated quite closely with their experience, doubly of triply alienated from origins" (p. 103).

While the process on the part of the colonised elites includes mockery, it also includes a threat to the coloniser. Understanding this is crucially important here, since what emerges in this process is a genre of post-colonial literatures, the ambivalence of which is 'menacing' to colonial discourse and forms of representation. The menace of mimicry, Bhabha (1994) argues does not lie in its concealment of some real identity behind its mask, but comes from its "double vision which in disclosing the ambivalence of colonial discourse also disrupts its authority" (p. 88). According to Bhabha, colonised mimics are not disempowered by the coloniser. Being invested with power, they threaten to disclose the ambivalence of the colonial discourse, which they anxiously attempted to conceal through the use of stereotypes. When hearing their language and values returning to them through the mouth of the colonised, they are faced with the 'worrying threat of resemblance' between the coloniser and the colonised. This threat has to collapse the 'Orientalist' structure of knowledge in which such oppositional distinctions are made. The ambivalence is a potential source of anticolonial resistance that offers an unconquerable challenge to the entire structure of colonial discourse. Drawing on Bhabha, Ashcroft et al., (2000) claim that the threat of post-colonial writing does not necessarily emerge from direct opposition to colonial authority, but comes from a disruption of colonial discourse. They contend: "the threat inherent in mimicry, then, comes not from an overt resistance but from the way in which it automatically suggests an identity not quite like the coloniser. This identity of the colonised subject-'almost the same but not white'- means that the colonial culture is always potentially and strategically insurgent" (p. 141). As such the act of mimicry on the part of colonised elites could be taken not as straightforward homage, but a means of eluding control. 
However, the fact remains that those mimics spoke out of a reality of social displacement and disintegration, expressing a consciousness that is removed from truth or reality. But it also remains true that colonised elites stood to gain from contact with the centre, since they were educated in colonial schools and injected with Western ideas and sentiments. The colonised elites' replication of European modernism, for instance, has revealed a process of global transculturation in literature that has continued to thrive. Walcott (quoted in Boehmer) suggests that colonised "patrician writers refracted European styles through the irony of their differential positioning, this offered strengths which were not at that stage obtainable elsewhere" (p. 165). Thus, this heterogeneous and limited tradition could be taken as an outbreak of colonial literature and an advent of post-colonial literatures.

\subsection{Theme Seven: A double vision of the colonised}

Generally, in the early literary movements that took the form of resistance and opposition to colonial authority, discourse and literature emerged out of interaction with colonial writings. According to Boehmer, the literatures of the early nationalist and other cultural movements found their ground in 'exchange' with the European literature that is shaped by a complicated formula of 'likenesses' and 'contrasts'. Those writers appropriated the coloniser's genres, symbolic conventions, and structures to express their own identity. Nevertheless,

To be true to oneself in borrowed robes: this was the dilemma of the colonial nationalist [...] The full dimensions of the question of self-articulation became clear when we consider that not only the language and literary traditions transmitted by a colonial education were British, but also the institutions and political ideologies through which autonomy was asserted [...] (Boehmer, 2005, p. 101).

With the rise of nationalist movements, Boehmer proceeds, colonised writers began to adopt the terms of articulation that were furnished by the colonial rule, and the expansion of the European nation-state in the era of colonialism that had spread a rhetoric of cultural self-determination. Therefore, the ethos of national autonomy that the colonial authority had propagated contributed to the rise of anti-colonial views. Yet, this was not easily achieved, since at the time when early native movements sought to deconstruct the colonial authority, they had in many cases appealed to the experience of the colonial discourse itself. This is because colonialism, like religious or political authority, claims a monopoly on definitions in order to control an unstable and diverse reality; it achieved its dominance through persistent incorporation and suppression of difference.

The crucial gain however was made through vigorous reiteration of authoritative meanings. Predictably, through nurturing, closure, and circulation of colonialist discourse, 'deviation' from the 'norm' was difficult. The complication of any form of resistance stems from the fact that early writers who wrote against the empire were the intellectuals who were being instructed in the excellence of English literature and the Western system of rationality, and more importantly the deficiencies of their own cultures. The knowledge that was made possible and available to them was within the colonial system: a framework that furnished their protest also entrapped them.

Resistance and identity movements gave expression to the largely imaginary identities that colonial discourse had attributed to the others. Such pictures of Western encirclement by the colonised intellectuals searching for agency might be taken as the 'double bind', where they were caught in a situation of 'split perception' or 'double vision'. They sought to challenge aspects of imperial rule by gaining advantage by making compromises with it in a double process of 'cleaving from and to Europe': "cleaving from, moving away from colonial definitions, transgressing the boundaries of colonialist discourse; and in order to effect this, cleaving to: borrowing, taking over, or appropriating the ideological, linguistic, and textual forms of the colonial power" (p. 101). Thus, many oppositional forms were seen as hybrids, following neither purely modern nor purely traditional models. This was the case especially in literature, where the early colonised writers, though aiming for resistance, found themselves developing the styles of identity in terms offered by their antagonists. Sedar Senghor (Senegal), Aime Cesaire (Martinique), and Bernard Binline Dadie (Ivory Coast) are early post-colonial writers who adhere to the tradition of British writers.

\subsection{Theme Eight: An epistemological leap}

Fanon, in his seminal psychological essay, Black Skin, White Masks (1967) radically invoked the self-determining powers of colonised people. He called them to resist decisively 'the arsenal of complexes' - paranoia, feelings of inferiority - created by colonial authority. He called for a thorough decolonisation in which the entire structure of the colonial system should be changed 'from the bottom up', and for freedom in the broadest sense. For him, this means a nation-independence, reformation of institutions, control over productive resources, belligerent defiance from writers and intellectuals, absolute opposition, liberation, and struggle, and active resistance on all fronts (political, economic, and cultural) without any space for compromise. Unlike former attempts to reverse racist stereotypes, Fanon argued that the struggle against the coloniser should aim not only a complete autonomy but the transformation of social and political consciousness. Culture for him is taken an important arena of transformation; a psychological and spiritual site in which freedom might be won.

To decolonise thoroughly indigenous are forcibly substituted for the alien, in literature as in life. In a similar vein, Thiong'o (1981) understands imperialism as a 'cultural bomb' that "is to annihilate a people's belief in their names, in their languages, in their environment, in their heritage of struggle, in their unity, in their capacities and ultimately in themselves" (p. 3) and calls for the 'oppressed and the exploited of the earth' to carry out defiance: for liberty and from theft. For him, imperialism makes the colonised people 'see their past as one wasteland', and to identify themselves 'with that which is furthest removed from themselves'; it plants serious doubts about the moral rightness of struggle, 
and amidst this wasteland which it has created, it, presents itself as the cure and demands that the dependant sing hymns of praise with the constant refrain: 'Theft is holy'. Within such conceptualisation, Thiong'o calls on the colonised to "wield even more firmly the weapons of the struggle contained in [the colonised] culture" (p. 4).

In this sense, twentieth-century writers participated in this struggle by refining literature. Anti-colonial resistance became the enabling context, a rallying topic, and a focal point. The role of literature helped transform social life and through 'education' or 're-education', it formed a basic sustaining force in a liberation struggle. Literature during the era of independence, according to Boehmer, projected autonomous identity by infusing people with a sense of their own unique identity, and created communal relationships within new national formations. Imagining the nation is a process of winning self-autonomy that requires a reconstruction of the nation in a collective imagination and a new symbolisation of identity. Literature, with its potential to compose alternative realities and inscribe new origins and historical trajectories, was seen to provide a rich medium for this purpose.

Additionally, in Decolonising Fiction, Brydon and Tiffin (1993) contend that to decolonise writing, writers had to claim the humanity denied under colonialism, combat the destructive inheritance of racism, and negate cultural negations ( $\mathrm{p}$. 177). Therefore, the "making [of] a post-colonial world meant learning how to live and represent that world in a profoundly different way" (ibid, 179). Post-colonial writers developed symbolic vocabulary that was to be recognisably indigenous, or at least other to European representation, and yet intelligible within the post-colonial world. In their search for authentic self-definition they turned to tales that testify to indigenous cultural richness, metaphysical systems, and predating the coloniser that had eluded their interpretative grasp.

Insisting on the link between cultural and political resistance, they explored the histories of anti-colonial struggle by recalling their own legends of ancestral valour against invading powers. They also sought to mend the obfuscating and self-cancelling disjunction between the coloniser's discourse and their lived reality; they attempted that through imagining the world from their own point of view. They established new metaphors of nationhood, "not only to rewrite history, but to create and to frame defining symbols for the purpose of imagining the nation" (Boehmer, p. 189). Achebe (quoted in Boehmer, p. 181) called on the writers to change the way the colonised world was seen, to tell their own stories, 'to wage a battle of the mind with colonialism by re-educating readers'. He remarks: "I think it is in part of my business as a writer to teach ... that there is nothing disgraceful about the African weather, that the palm tree is a fit subject for poetry" (p. 181). Literature allowed for the dramatisation of moments of indigenous resistance. In short, post-colonial writings emphasised the importance of unity from within, 'cleaving to one's own': 'control, self making or selving, and form-giving' (ibid, p. 196-9).

\subsection{Theme Nine: Hybridisation and Diaspora}

Hybridisation, nevertheless, remained a distinctive feature of post-colonial literatures. Post-independence writers relied on an intensely practical hybridity: 'the blending of their different cultural influences', an upfront and active syncretism with the aim of uninstilling the inheritance of Europe. Their narrative tradition is seen to negotiate between different registers: "between high and low voices, and contrasting realities, past and future, First and Third World, elite and mass" (Boehmer, p. 230). Such a polyphonically crafted hybridity has encouraged poststructuralist critics to see in postcolonial literature "an amplification of the dialogic quality which the critical theorist Mikhail Bakhtin once defined as the particular property of the novel” (ibid, p. 231). The 'in-between' position of identity has preoccupied post-colonial writers calling on post-colonial theorists to create new and dynamic ways of thinking about identity that go beyond static models like national identity. This is where the match between post-colonial theory and post-colonial literature takes place. Borrowing its terminology from Bhabha, post-colonial texts are seen to have a migrant identity of 'hybridity writ large and in colour' (ibid, p. 232). It is diagnostic of the bewildering array of cultural translations that writers of the diaspora have established. A transnational and translational genre of aesthetics produces itself as a 'mosaic' seeking "symbols and patterns with which to explain the world on various planes of experience - in phrenology and weaving technique and in the theory of queues" (ibid, p. 227).

Nonetheless, hybridity in arts remains primarily a symbolic device, and a source of themes that represent connections of diasporic writers whose backgrounds remain chiefly metaphorical. In short, hybrid post-colonial literature has adopted a dialogic and multi-voiced, conceptualisation of the world and expresses that world in plural, 'noisy', 'authentic', and 'street-muddied' narratives. Additionally, McLeod (2000) views thinkers who are located within the triangulation of diaspora, migration, and post-coloniality as "creating new ways of thinking about individual and communal identities, critiquing established schools of critical thought, and rethinking the relationship between literature, history and politics" (p. 208).

\subsection{Theme Ten: Afterwards}

'Neo-colonial' problems have been increasingly dominating post-independence nations, such as economic disorders, social malaise, government corruption, and state repression. Globalisation, 'the definitive condition of twenty-firstcentury humanity', has emerged as another challenge to post-colonial writers. Viewing these conditions, Boehmer (2005) argues "in much of the once-colonised world, decolonisation in fact produced few changes: power hierarchies were maintained, the values of the former coloniser remained influential" (p. 231). In the literary context, diasporic writers have challenged the conventional stereotypes and modes of thinking.

In the current conditions of cultural, social, academic, and literary spheres, post-colonial societies still experience a continuing imposition of colonialism. Given these conditions, post-colonial writers and readers remain interested in the 'discursive traces' of colonial discourses, whether inherent in the text or in the world, and their work continues to 
excavate them. Contemporary globalised imperialism, such as the recent invasions of refugee camps in Palestine under formal Western authority and the global 'war on terror' waged by America and its allies are rendered in ways international laws are powerless to address ( $\mathrm{ibid}$ ).

Post-colonial writers and thinkers have reproduced the imperial discourse that continues to inflict its authority. In response to such developments, post-colonial, humanist, and post-humanist writers have split in two main groups. Some have been concerned with rearticulating global relations in their writings about the Western cultural hegemony. Considering the role of the 'trans-societal flows', the 'borderless global economy', and the electronic communications in undermining the former centrality of national and institutional structures, where global interconnections have ramified to an extent that this route of post-colonial literature is widely seen as a reflection or a re-figuration of that globalised world. The second group, however, have extended their post-colonial ethical and activist agendas. They continue to question the term 'globalisation', refusing to take it as its word, and deeming it a 'sensorily stimulating' and 'allegedly post-imperial' word (ibid).

\section{Conclusion}

To begin with the end, although the last theme is intended to be a closing section of this narrative, the word 'afterwards' might become illusionary as it indicates an arch-shift or an epoch-making moment in English literature. The aim is, rather, to establish a persistent conceptualisation of literature that as a social action not only impacts, but is also impacted by its immediate context. The afterwards then is another link in this chain, and the 'post' in 'post-colonialism' is not for the past but for the present and even might be for the future.

Building on this, several conclusions might be drawn: first, this narrative accentuates the argument that literature is a fluid and indissoluble epiphenomena of cultural, social, and to certain extent political constructions. Vidal (1993), arriving at a similar conclusion, maintains that in its origin and development "literature is a conception and a tool for social construction and an indirect weapon in political struggle ... and thus moved closer to symbolic anthropology, sociology, and political science" (p. 114). This argument turns the possibility of this conceptualisation against received notions claiming that English literature embodies humanist, universal and trans-historical values.

Additionally, each era has a distinctive theme that endorses a germane link of literature to its social context. Privileging and authorising 'masterpiece texts' of one era or perspective is an act of hegemony that throttles other legitimate views of the world. When maintaining a balance of texts of different representations, where different peoples and cultures in a variety of texts are written from both post-colonial and Eurocentric perspectives, these texts are put in dialogue so as to have students generate readings and writings about each that use both to help describe and question inscriptions of power. Hulme (1994, quoted in Loomba, 1998) suggests that while teaching European canons might be useful, "we need to pay attention to the historical and political nuances of texts produced in the elsewhere colonies" (p. 74).

Second, such conceptualisation of literature helps to explain some of the particular ways in which studying literature can offer challenges to simple and objectivist views of knowledge. Such awareness suggests that texts may be read as indicative of privileged values and beliefs; they have a political dimension and are not simply representations of the author's de-contextualised personal truth (Ricouer, 1978). The study of literature in relation to its social context and how that context is related to literature opens further possibilities in which a better understanding of both could be achieved. This assumption requires that literature be read in more contextualised ways, and suggests that social and historical processes are textual in the sense that they are made available to us vis-à-vis their representations, which involve diverse ideological and rhetorical strategies as much as they involve fictional elements (Loomba, 1998). It furthermore challenges the belief that texts are neutral and apolitical, and encourages the realisation that knowledge is never value-free. This in turn helps learners develop critical reading skills and encourages them to question the takenfor-granted assumptions about the veracity of literature. Forevermore, this narrative directly challenges the assumption that Western canonical literature and the tradition of post-colonial culture and literatures of the 'Third World' are homogeneous categories (Bennet, 1994; McCarthy et al., 1997).

Finally, the re-conceptualisation of literature as a political tribute is crucially important to arguing against the monolithic tradition of imposing the Western canon at post-colonial education institutions.

\section{References}

Achebe, C. (1965). The Novelist as Teacher. In Press, J. (Ed.), Commonwealth Literature: Unity and Diversity in a Common Culture (pp. 201-5). Brookfield: Heinemann.

Althusser, L. (1971). Ideology and Ideological State Apparatuses. In L. Althusser (Ed.), Lenin and Philosophy and other Essays. New York: Monthly Review Press.

Ashcroft, B., Griffiths, G., \& Tiffin, H. (1989). The empire writes back: Theory and practice in post-colonial literature. London: Routledge.

Ashcroft, B., Griffiths, G., \& Tiffin, H. (1995). General introduction. In Ashcroft, B., Griffiths, G., \& Tiffin, H. (Eds.), The Post-colonial Studies Reader. London: Routledge.

Ashcroft, B., Griffiths, G., \& Tiffin, H. (1999). The postcolonial studies reader. London: Routledge.

Ashcroft, B., Griffiths, G., \& Tiffin, H. (2000). Postcolonial studies: Key concepts. London: Routledge

Bauman, Z. (2000). Liquid Modernity. Cambridge: Polity Press in association with Blackwell. 
Bauman, Z. \& Tester, K. (2001). Conversations with Zygmunt Bauman. Cambridge: Polity Press in association with Blackwell Publishing.

Bhabha, H. (1990). Nation and narration. New York: Routledge.

Bhabha, H. (1994). The location of culture. London: Routledge.

Bhabha, H. (1996). Cultures in between. In Hall, S. \& Du Gay, P. (Eds.), Questions of Cultural Identity (pp. 53-60). London: Sage Publications

Boehmer, E. (2005). Colonial \& postcolonial literature ( $2^{\text {nd }}$ edition). Oxford: Oxford University Press

Bourdieu, P. (1983). The forms of capital. In Richardson, J. (Ed.), Handbook of Theory and Research for Sociology of Education. New York: Greenwood Press.

Bourdieu, P. (1984). Distinction: A social critique of the judgment of taste. Harvard: Harvard University Press.

Brydon, d. \& Tiffin, H. (1993). Decolonising fiction. Sydney: Dangaroo Press.

Carey, J. (1992). The intellectuals and masses: Pride and prejudice among the intelligentsia, 1880-1939. London: Faber.

Chin, G. (2006). The anxieties of authorship in Malaysian and Singaporean writings in English: Locating the English language writer and the question of freedom in the postcolonial era. Postcolonial Text, 2, 1-24.

Culler, J. (1997). Literary theory: Avery short introduction. Oxford: Oxford University Press.

Eagleton, T. (2000). The idea of culture. $2^{\text {nd }}$ ed. London: Blackwell.

Eagleton, T. (2008). Literary theory: An introduction, anniversary Ed. London: Blackwell.

Easthope, A. (1991). Literary into cultural studies. London: Routledge.

Fanon, F. (1967). Black skin, white masks. New York: Grove.

Fowler, A. (1999). Civil society, NGDOs and social development: Changing the rules of the game. Geneva 2000 Occasional Paper, 1. UNRISD, Geneva.

Graft, G. (1987). Professing literature: An institutional history. London: The University of Chicago Press.

Gramsci, A. (1971). Selections from the Prison Notebooks. Hoare, Q \& Nowell Amith, J. (Trans. \& Eds.). New York: International Publisgers.

Gilory, P. (2005) Postcolonial Melancholia. Colombia University Press

Guillory, J. (1993). Cultural capital: The problem of the literary canon formation. Chicago: University of Chicago Press.

Hall, G. (2005). Literature in language education. London: Palgrave Macmillan.

Holliday, A. (1999). Small cultures. Applied Linguistics: Software of the mind. London: Harper Collins Business.

Hunter, L. (2001). Literary value/cultural power: Verbal arts in the twenty-first century. Manchester: Manshester University Press.

Jameson, F. (1986). Third-World literature in the Era of Multinational Capitalism. Asocial Text, 15, pp. 65-88.

Janssen, S. (1988). Institutional factors influencing the selection made by literary reviewers. SPIEL/Siegener Periodicum, 7, 281-291.

Janssen, S. (1997). Reviewing as social practice: Institutional constraints on critics' attention for contemporary fiction. Poetics, 24, 275-297.

Loomba, A. (1998). Colonialism/Postcolonialism. London: Routledge.

Loomba, A. (2005). Colonialism/postcolonialism. $2^{\text {nd }}$ ed. London: Routledge.

MacLeod, J. (2000). Beginning Postcolonialism. Manchester: Manchester University Press.

Rosengren, K. (1998). The climate: A sea Change? Media and Communication Studies. Poetics, 24, 311-326.

Said, E. (1990). 'Third World' intellectuals and the metropolitan culture. Raritan, 9, 27-51.

Said, E. (1978). Orientalism. Harmondworth, London: Penguin.

Said, E. (1983). The world, the text, and the critic. Cambridge, Mass: Harvard University Press.

Said, E. (1985). Beginnings: Intention and method. New York: Colombia University Press.

Said, E. (1993). Culture and imperialism. London: Chatto \& Windus.

Said, E. (1994). Culture and imperialism. London: Vintage.

Said, E. (1995). Orientalism: Western conceptions of the Orient. Harmondsworth: Penguin.

Said, E. (2001). Globalizing literary study. PMLA, 116, 64-68.

Spivak, G. (1985). Strategies of vigilance: An interview conducted by Angela McRobbie, Block, 105-9. 
Spivak, G. (1988). Can the subaltern speak? In Nelson, C. \& Grossberg, L. (Eds.), Marxism and the Interpretation of Culture (pp. 271-313). Chicago: University of Illinois Press.

Thiong'o, N. (1981). Decolonising the mind: The politics of language in African literature. Brick Court, Nairobi: East African Educational.

Eliot, T. S. (November 1923). Ulysses,' Order and Myth. Rev. of Ulysses by James Joyce. The Dial.

Verdaasdonk, H. (1983). Social and economic factors in the attribution of literary quality. Poetics, 22, 373-388.

Verdaasdonk, H. (1994). Analogies as tools for classifying and appraising literary texts. Poetics, 13, 273-388.

Verdaasdonk, H. (2001). Quatations expressing the valuative stands of literary reviews. In Schram, D. \& Steen, G. (Eds.), The psychology and sociology of literature (pp. 379-394). Amesterdam: Benjamins.

Vidal, H. (1993). The concept of colonial postcolonial discourse: A perspective from literary criticism. Latin America Research Review, 28, 113-119.

Westhuizen, C. (2004). Judging the book. Journal for Language Teaching, 38, 144-157.

Williams, R. (1958). Culture and society. London: Chatto \& Windus.

Williams, R. (1961). The long revolution. New York: Colombia University Press.

Williams, R. (1976). Keywords: A vocabulary of culture and society. London: Fontana. 